\title{
Richard Sulík: A provincial or a European Slovak politician?
}

\author{
Stefan Auer
}

Richard Sulík, a controversial Slovak political leader, embodies the conflicting nature of Slovak nationalism(s) since 1989. It has been argued that the process of post-communist transition in Central Europe has been driven by contradictory forces of liberal/illiberal, civic/ethnic and Eastern/Western nationalisms. Slovakia is no exception. Sulík's personal story and his political career shed light on these developments. This is in line with the expectations, articulated by Jonathan Hearn in this issue, that 'no matter how unique, individual, personal cases of national identity, in all their specificity, will provide clues to how more general social patterns of national identification are formed'. ${ }^{1}$ Sulík's short political career to date has reflected and shaped Slovak self-understanding.

This article takes as its point of departure Hearn's typology of 'moods', by situating its protagonist as someone who acted self-consciously 'against the flow', even paying a significant political price for his convictions (though with a clear expectation that he would 'be ultimately justified'). ${ }^{2}$ Through his lived experience, multilingualism and outlook, Sulík could be viewed as a perfect example of a modern European politician. Like a majority of Slovaks, he was initially an enthusiastic supporter of Slovakia's membership of the European Union, including its membership in the single currency. His enthusiasm turned to scepticism when his hopes about Europe as an anchor of stability were disappointed. Sulík's determined stance towards one of the defining issues of contemporary Europe - the eurozone crisis that threatens the European project at large - led to his political isolation in Slovakia, and earned him a mixture of admiration and contempt in Germany, where he spent his formative years as an adolescent. As a result of his uncompromising views on euro-rescue policies, Sulík has been criticised as a populist, or even an extreme nationalist, particularly after the October 2011 vote on the increase of the eurozone bailout fund in the Slovak Parliament, which brought down the Government, necessitating early elections. Undeterred, Sulík revelled in his Europe-wide reputation as an

1 Hearn, this volume.

2 Hearn, J. 2002, 'Narrative, agency, and mood: on the social construction of national history in Scotland', Comparative Studies in Society and History, vol. 44, no. 4, pp. 745-69, at p. 750. 
'oddball', ${ }^{3}$ and though his popularity amongst Slovak voters has not increased, his political prospects may yet benefit from further deterioration of the eurozone crisis.

\section{Nationalism and Biography in Central Europe}

There is an obvious connection between biography and nationalism in the postcommunist world. Strong personalities matter for any 'imagined community', but during times of radical change nations are even more likely to depend on charismatic leadership. As George Schöpflin astutely observed immediately after the collapse of communism in Central and Eastern Europe:

Almost hypnotically, people turned to personalities, virtually without regard to their political programmes, as a repository for society's hopes and desires in particular, because persons were felt to be more reliable, more authentic and thus more likely to embody what the individual wanted. In this way personalities were invested with what amounted to a suprapolitical status. ${ }^{5}$

The post-1989 ideological vacuum could not have been filled by robust institutions (which were yet to be created) or alternative ideologies (which were yet to be articulated to harness public support); it was hence filled by strong leaders, spaning from enlightened, liberal and pro-Western leaders such as Václav Havel in Czechoslovakia, and, after 1993 in the Czech Republic, to narrow-minded, chauvinistic demagogues such as Vladimír Mečiar in Slovakia. ${ }^{6}$ Indeed, one of the pathologies of post-communist societies was people's proclivity to support populist leaders whose all too often rather incoherent political programs were far less important than their personal charisma. Sulík is not charismatic, ${ }^{7}$ and he

3 "'I'd rather be an oddball in Brussels than feeling ashamed in front of my children, who would be deeper in debt should I back raising the volume of funding in the EFSF bail-out mechanism", Parliamentary Chairman and head of co-governing Freedom and Solidarity (SaS) party Richard Sulik said in Parliament on Tuesday.' TASR, News Agency of the Slovak Republic, 11 October 2011, <http://195.46.72.16/free/jsp/search/ view/ViewerPure_en.jsp?Document=..\%2F..\%2FInput_text\%2Fonline\%2F11\%2F10\%2Ftbbvabg034463. dat. $1 \% 40$ Fondy \&QueryText $=>$

4 Anderson, B. 1991, Imagined Communities: Reflections on the origin and spread of nationalism, [Second edn], Verso, London.

5 Schopflin, G. 1993, Politics in Eastern Europe, 1945-1992, Blackwell, Oxford, p. 268.

6 For studies on Mečiar's impact on Slovak politics in the 1990s, see, for example: Williams, K. 2000, Slovakia after communism and Meciarism, SSEES Occasional Papers 47, School of Slavonic and East European Studies, London; Haughton, T. 2005, Constraints and Opportunities of Leadership in Post-Communist Europe, Ashgate, Aldershot, UK.

7 The billboards that Sulík employed in his 2010 election campaign openly alluded to his lack of charisma by stating next to his depiction, 'Fešák nie som, ale hrám fér', which can be translated loosely as, 'I might not be handsome, but I play a fair game'. 
is, in fact, unlikely to ever become as influential as the likes of Havel or Mečiar. Yet, his story is revealing about Slovak nationalism in the way in which his position towards Europe highlighted new divisions within Slovak society.

Central Europe was a testing ground for competing theories of nationalism well before scholars started to ponder the challenges of post-communist democratisation. There is no need to rehearse arguments here about the conflict between primordialists and modernists ${ }^{8}$ - that is, those scholars who viewed nations as going back to ancient times ${ }^{9}$ and those who argued that they emerged as a result of modernisation, and were thus invented as recently as the eighteenth or nineteenth century. ${ }^{10}$

Whatever theoretical camp they belonged to, most experts on nationalism after 1989 were united in seeing it as a threat to the process of democratisation in Central Europe, particularly in a country like Slovakia. Scholars were reminded of the old conceptual division between civic and ethnic nationalism that can be traced back to Hans Kohn. ${ }^{11}$ John Plamenatz restated the concept in the 1970s and sharpened the geographical focus of this theoretical device by differentiating between the Western and the Eastern kind of nationalism. ${ }^{12}$ This distinction remains influential: the first kind of nationalism was meant to be positive, because it was civic, it was by definition forward looking, tolerant and enlightened; the second one was negative, because it was ethnic, backward looking and intolerant. Civic communities were meant to be open to newcomers, because their membership was defined by certain political values, rather than descent or culture. Ethnic nations, in contrast, were said to base their membership on birth and were hence more exclusive, tending towards chauvinism. For Kohn, Plamenatz and their countless followers, civic nationalism was characteristic of nations in Western Europe, such as France and the United Kingdom, while ethnic nationalism was typical of nations in Eastern Europe, such as Slovakia. It is worthwhile noting that these conceptual boundaries have shifted over time: Germany was initially seen as typically Eastern (that is, by Kohn), only to be declared typically Western a few decades later (that is, by Plamenatz). ${ }^{13}$ In a

\footnotetext{
8 I am inclined to side with Hearn's assessment 'that there are problems with both primordialist and modernist approaches, and that the fruitfulness of framing the debates in terms of this antinomy may be exhausted'. See Hearn, J. 2006, Rethinking Nationalism, Palgrave Macmillan, Houndmills, UK, p. 229.

9 Scruton, R. 1990, The Philosopher on Dover Beach, Carcanet, Manchester; Smith, A. D. 1991, National Identity, Penguin, Harmondsworth, UK.

10 Anderson, Imagined Communities; Gellner, E. 1983, Nations and Nationalism, Blackwell, Oxford; Hobsbawm, E. 1990, Nations and Nationalism Since 1780: Programme, myth, reality, Cambridge University Press, Cambridge.

11 Kohn, H. 1945, The Idea of Nationalism: A study in its origins and background, Macmillan, New York.

12 Plamenatz, J. 1973, 'Two types of nationalism', in E. Kamenka (ed.), Nationalism, ANU Press, Canberra, pp. $22-37$.

13 Plamenatz's categorisation ignored the fact that West Germany continued to define its citizenship by descent.
} 
similar vein, the Czechs were promoted to being a typically Western nation shortly after $1989,{ }^{14}$ while the Slovaks had to wait almost two decades to acquire such status.

This 'academic nationalism'15 finds its predecessor in popular culture. An amusing encounter with a stereotypical Slovak occurs, for example, in Bram Stoker's Dracula, in which a traveller heading for Transylvania observes, 'the strangest figures...the Slovaks, who are more barbarian than the rest, with their big cowboy hats, great baggy dirty-white trousers, white linen shirts'. The fictional traveller is also bothered by the lack of efficiency, complaining that 'the further East you go the more unpunctual are the trains'.$^{16}$ In a similar vein, Agatha Christie's invented country 'Herzoslovakia' is populated by people who are 'picturesque', but also 'very reactionary' and 'most uncivilized'. Their national 'hobby' is 'assassinating kings and having revolutions'. Although the reader does not learn much about Herzoslovakia's geography, the country clearly represents the Eastern Europe of Western imagination. ${ }^{17}$ A great deal of similar images can still be found in popular media across Western Europe.

Yet, there is a growing realisation that Kohn's East-West dichotomy is unhelpful in understanding different sources of nationalist mobilisation in Europe. As Roger Brubaker demonstrated, 'nationalism resists neat parsing into types with clearly contrasting empirical and moral profiles'. Brubaker's argument that 'the civic-ethnic distinction is overburdened'18 echoes earlier findings by David Brown, who questioned whether we should differentiate between 'good and bad nationalisms'. ${ }^{19}$

Clearly, the theory of two kinds of nationalism in Europe tends to obfuscate rather than explain differing qualities of nationalist mobilisation. As I have argued more specifically in relation to Central Europe, ${ }^{20}$ this theory is

14 Kořalka, J. 1994, 'Hans Kohns Dichotomie und die neuzeitliche Nationsbildung der Tschechen', in E. Schmidt-Hartmann (ed.), Formen des nationalen Bewußtseins im Lichte zeitgenössischer Nationalismustheorien, R. Oldenburg Verlag, Munich, pp. 263-75.

15 Drakulić, S. 2011, 'Academic nationalism', in T. Harrison and S. Drakulić (eds), Against Orthodoxy: Studies in nationalism, University of British Columbia, Vancouver, pp. 17-38.

16 Stoker, B. 2002 [1897], Dracula, J. P. Riquelme (ed.), St Martin's Press, New York, pp. 28-9.

17 Agatha Christie created Herzoslovakia as a background to one of her many murder-mystery stories. Her invented country is politically unstable and threatens the peace in Europe. Christie thus created an archetype of a small Eastern European country by bringing together the Balkans and Central Europe. The name is an amalgam of Herzegovina and Czechoslovakia. Christie, A. 2001 [1925], The Secret of Chimneys, St Martin's Minotaur, New York, pp. 8, 54, 123.

18 Brubaker, R. 2004, "Civic" and "ethnic" nationalism', in Ethnicity without Groups, Harvard University Press, Cambridge, Mass., pp. 132-46, at p. 146. 'Sometimes, as in Kohn's work', Brubaker argues, 'this distinction is projected in space, and used to contrast the civic nationalism of Western Europe...with the ethnic nationalism of Eastern Europe or other world regions. Such grand contrasts of world regions easily acquire a neo-orientalist flavor' (p. 133).

19 Brown, D. 1999, 'Are there good and bad nationalisms?', Nations and Nationalism, vol. 5, no. 2, pp. 281-302.

20 Auer, S. 2004, Liberal Nationalism in Central Europe, Routledge, London. 
problematic for two main reasons. First, its crude reductionism has the potential to 'condemn' entire nations to being illiberal by their natural predisposition; in other words, it deems them insufficiently civilised or even barbaric. Second, the theory prevents us from realising that different kinds of nationalism compete for dominance within each nation - indeed within any political community that shows some level of social cohesion. This became relevant after 1989, when many observers simply assumed that the prospects for liberal democracy in Central and Eastern Europe would be seriously undermined by the rise of extremist nationalism. The violent disintegration of Yugoslavia seemed to have confirmed some of these assumptions, while the apparent success of democratisation in the Czech Republic after the disintegration of Czechoslovakia in 1993 appeared to have defied it (and so the Czechs were simply labelled a Western nation as noted above). At any rate, despite the obvious shortcomings of such a simplistic approach to nationalism, in the 1990s the theory of 'two kinds of nationalism' dominated the thinking of many political scientists within the field of European studies.

Following this logic, Milada Vachudová and Tim Snyder differentiated between 'two types of political change in Eastern Europe', contrasting the Poles, Hungarians and Czechs with the Slovaks, Bulgarians and Romanians. They argued that 'the most striking and important feature dividing [the two groups] is the role of ethnic nationalism in domestic politics' ${ }^{21}$ Jack Snyder expanded on this theory, claiming that 'the sophisticated Czechs were able to invent a working civil society virtually overnight', while 'more rural and less sophisticated' people in Serbia, Slovakia and Romania were more likely to be tempted by 'counterrevolutionary nationalist appeals by former communist leaders' ${ }^{22}$

\section{Liberal Nationalism in Slovakia}

Slovakia presented a fascinating case. As we have seen, in the early 1990s the country appeared to have vindicated those scholars who doubted Eastern European prospects for democratisation. After it reclaimed its independence in 1993, Slovakia drifted towards an illiberal democracy led by an authoritarian leader, Vladimír Mečiar, who showed disregard for the basic principles of freedom of the press and undermined the establishment of the rule of law. Yet, towards the end of that decade, and even more so after 2000, Slovakia was seen (and saw itself) as being back in the heart of Europe.

21 Vachudová, M. and Snyder, T. 1997, 'Are transitions transitory? Two types of political change in Eastern Europe since 1989', East European Politics and Societies, vol. 11, no. 1, pp. 1-35, at p. 2.

22 Snyder, J. 2001, From Voting to Violence: Democratization and nationalist conflict, Norton, New York, p. 73. 
The question at the heart of Slovak nationalism (of every nationalism?) is simply: who are the Slovaks? For European nations, this question is also about their role in Europe. Most Slovaks like to think of themselves as good Europeans, which is positively reflected in their perception of the European Union. Numerous Eurobarometer surveys have consistently shown that a very strong majority of Slovaks view EU membership as beneficial. ${ }^{23}$ Even Mečiar was forced to present himself as being pro-European. This is not to ignore the fact that he also used extreme nationalist rhetoric whenever he believed it opportune. In fact, the growing discrepancy between Mečiar's rhetorical commitment to Europe and the reality of increased isolation from Europe eventually contributed to his demise. Mečiar's authoritarian tendencies displayed, for example, in his attempts to constrain the freedom of the media could not have been tolerated by a European Union committed to certain democratic standards. Eventually, Mečiar ended up entangled in an 'argumentative self-entrapment', claiming that Slovakia's destiny was its full integration in the European Union, all the while not being able to deliver on that goal. ${ }^{24}$

The traditional societal cleavage, which had shaped Slovak political developments in the 1990s, was the one between a more ethnocentric nationalism that was hostile to the outside world, including Europe, and a liberal strand of nationalism that saw no inherent contradiction between the aims of European integration and national emancipation. This contest appeared to be won by liberal-nationalist forces in the 1998 elections, which were dubbed by some observers as the 'Second Velvet Revolution' ${ }^{25}$

Sharon Fischer, for example, believed that the 'peaceful civic revolution' in 1998 transformed post-communist Slovakia from 'Nationalist to Europeanist'. As she argued, Slovakia's

quest for independence and the challenges of democratization created a contest between two powerful forces in domestic politics after the collapse of communism: the 'Nationalists,' who stressed the importance

23 In the Spring 2011 survey, for example, 72 per cent of respondents believed that Slovakia's EU membership had been beneficial. Only Ireland (78 per cent), Poland (73 per cent) and Luxembourg (73 per cent) showed higher levels of support. This is remarkable also against the background of worsening crisis in the eurozone and the controversy about the first bailout package for Greece, negotiated in 2010. Standard Eurobarometer 75, Public Opinion in the European Union, Spring 2011, viewed 31 May 2012, <http://ec.europa. eu/public_opinion/archives/eb/eb75/eb75_publ_en.pdf> pp. 34-5.

24 Auer, S. 2009, 'Slovakia: from marginalization of ethnic minorities to political participation (and back?)', in B. Rechel (ed.), Minority Rights in Central and Eastern Europe: Success or failure of EU conditionality, Routledge, London, pp. 195-209.

25 Bútora, M. and Bútorová, Z. 1999, 'Slovakia's democratic awakening', Journal of Democracy, vol. 10, no. 1 , pp. 80-95. 
of national sovereignty even at the risk of international isolation, and the 'Europeanists,' who believed that their country's brightest future lay in Western integration. ${ }^{26}$

Fischer went so far as to suggest that post-1998 Slovakia entered into 'the postnationalist period', in which 'the lines between the two sides [nationalists and Europeanists] have largely disappeared, as new divisions have developed that are more typical of Western societies' ${ }^{27}$ This confident assessment was proven wrong just at the time of the book's publication. The result of the June 2006 elections marked a setback for those political forces in Slovak society that combined their commitment to Europe with a clear rejection of ethnocentric nationalism. The elections empowered the young populist leader of 'Smer [Direction]-Social Democracy', Robert Fico, to lead a coalition government that included the extremist Slovak Nationalist Party alongside Mečiar's People's Party-Movement for a Democratic Slovakia (whose democratic credentials had already been discredited in 1992-98 as noted above). Even Fico did not shy away from nationalist rhetoric, his pro-European stance notwithstanding. Undoubtedly, the 2006 elections weakened liberal-nationalist strands in Slovak society, with the Government stirring anti-Hungarian sentiment and advocating policies of economic nationalism. Fico's increasing domination of the Slovak political sphere was halted temporarily in 2010 when a centre-right and emphatically pro-European Union coalition defeated him, but he returned to power thanks to a strong victory in the March 2012 elections.

In any case, Slovakia's post-1989 development exposed the limitations of theories of nationalism that depended on crude binary oppositions - whether Western and Eastern, civic and ethnic or indeed 'Europeanist' and 'nationalist'. It is unhelpful to differentiate between civilised and uncivilised nations; rather each nation has faced divisions from within about the right conception of what it means to be Czech, Slovak or Polish. Amongst those competing conceptions, there was always a strong presence in Central and Eastern Europe of liberal nationalism, which allowed for the combination of universal liberal values with a strong attachment to one's national community. Clearly, such a blend of liberal values and nationalism is also conducive to the key aims of European integration. A liberal nationalist is by definition a good European, because he rejects a chauvinist vision of his nation that prioritises its narrowly defined

\footnotetext{
26 Fisher, S. 2006, Political Change in Post-Communist Slovakia and Croatia: From nationalist to Europeanist, Palgrave Macmillan, New York, p. 209.

27 Ibid., pp. 8, 13. Vít Hloušek and Lubomír Kopeček echoed this assessment, arguing that 'nationalistic cleavage of transformation' lost relevance after 'the Slovak accession to the EU on the 1st May 2004'. Hloušek, V. and Kopeček, L. 2008, 'Persistence and change: cleavages in the contemporary Czech and Slovak politics', East European Politics and Societies, vol. 22, no. 3, pp. 518-52, at p. 545.
} 
interests above anything else. A number of influential Slovak political leaders fell into this category, ${ }^{28}$ amongst them the founder of Freedom and Solidarity (SAS), Richard Sulík.

This is not to ignore the fact that the very term 'a good European' is open to contestation, just as is the case with regard to the basic question of national identity. The answer to the question of 'who are the Slovaks', for example, is usually shaped by the respondent's normative views about Slovaks' desirable traits and their role in the world. In line with this, the political contestation about Slovakia's place in Europe is often pursued through conflicting visions about Slovak national identity. The same applies to the debates about the European Union's future and European identity.

At any rate, the eurozone crisis in 2011 dramatically changed the defining political cleavages in Slovakia, when a radical split emerged within the liberalnationalist camp about Slovakia's role in Europe. Sulík was instrumental in this story. Having been elevated to the prominent position of Speaker of the Slovak Parliament thanks to the June 2010 elections, in which conservative and liberal parties opposed the bailout of Greece, he found himself and his party isolated when rejecting similar policies more than a year later.

Martin Šimečka, a Slovak journalist based in Prague, spoke for many Slovak liberals when he observed in a lengthy interview for an influential Slovak TV program, Pod lampou:

What we have witnessed is a paradigmatic change in Slovak politics. I consider nowadays Richard Sulik and his entire party, SAS, as a radical right-wing party, which is extremist, populist and anti-European, at the same level as [the party] of Geert Wilders in the Netherlands. What I find particularly shocking on this phenomenon is the fact that this party emerged from within the reformist spectrum of Slovak politics... This fundamentally changes our situation. The division [that we have accepted to date as our founding myth] between us, 'the goodies', who oppose them, 'the baddies', such as Mečiar and Fico, lost its credibility, because this purely extremist party came into existence from our side of the political divide. ${ }^{29}$

Similar allegations against Sulík were made on high-impact political talk shows on German television. Sulík was attacked as an irresponsible populist stirring extreme nationalist sentiments by prominent politicians, from the

28 See the chapter on Slovakia in Auer, Liberal Nationalism in Central Europe.

29 Hríb, Š. 2011, 'Lampa o páde vlády a eurovale', Pod lampou, 14 October, <http://www.tyzden.sk/lampa/ lampa-pad-vlady.html> 
Social Democratic leader of the European Parliament, Martin Schulz (SPD), ${ }^{30}$ the former Mayor of Hamburg, Klaus Von Dohnanyi (also SPD), to the parliamentary Secretary and Deputy Finance Minister, Steffen Kampeter, from the ruling conservative Christian Democratic Party (CDU). ${ }^{31}$

In contrast, in the eyes of his numerous supporters at home, Sulík represented a stand that was both pro-European and responsive to Slovak national interests. ${ }^{32}$ The Slovak TV broadcast cited above also included comments sympathetic to Sulík's resistance of further mutualisation of debt across the eurozone. The actress, writer and singer Lucia Piussi noted pithily, 'Europe broke in [to Slovakia], and we lost sovereignty'. ${ }^{33}$ The respected theatre director Blaho Uhlár echoed that sentiment, bemoaning that Sulík's isolation confirms what he had felt for a long time: 'that this [Slovak] nation is fundamentally a nation of subservient subject people and Europe is feudal [in its structures]. European aristocracy demands more money and whether their subjects like it, or not, they will have to pay.' ${ }^{34}$

Virtually identical was the assessment by the political commentator Dag Daniš, in the same broadcast as well as in a Slovak financial daily newspaper. Daniš argued that the Slovak nation, by first attempting to defy and then being forced to comply with EU demands to increase the bailout fund, behaved like 'a servant who dares to use his own money as he pleases and ends up being punished and constrained in his freedom'. According to Danišs, Sulík became a victim of the German and French change of heart about EU policies with respect to the eurozone. As a result of his principled opposition to these misguided measures, Daniš argued, 'Sulik ended up in the [political] wilderness'. ${ }^{35}$

\section{Who is Richard Sulík?}

Who is Richard Sulík and what political values does he stand for? Were Sulík's many critics, or rather his supporters, right? Undoubtedly, Sulík is an unlikely candidate for a populist, an anti-European, let alone a 'provincial' Slovak. He is fluent in English and German, and no less comfortable appearing on German

\footnotetext{
30 Illner, M. 2012, 'Sind die Griechen noch zu retten?', ZDF, 2 February.

31 Will, A. 2011, 'Die Euro-Abstimmung - Riskieren wir jetzt alles?', ARD, 26 September.

32 This resonates with Sulík's self-understanding. As he put it in an interview with the author, 'I am a European, but I am also a Slovak. But when there are European issues, which damage Slovak interests then I oppose them. I am not so blinded by Europe...Yet, there are many nonsensical measures emanating from EU bureaucracy that I oppose regardless of my nationality.' An interview conducted in Bratislava on 26 June 2012.

33 Hríb, 'Lampa o páde vlády a eurovale'.

34 Ibid.

35 Daniš, D. 2011, 'Slovensko stratilo suverenitu', Hospodárske noviny, 14 October, < http://www.hnonline. sk>
} 
TV, addressing an audience at the Cato Institute's Centre for Global Liberty and Prosperity in Washington, DC, or the prestigious St Gallen Symposium in Switzerland, ${ }^{36}$ than he is when addressing his Slovak electorate.

The sudden rise to power of Sulík, a highly unconventional (a)political figure, occurred in the June 2010 elections, when his newly created (and largely unknown) party, Freedom and Solidarity (SAS), secured 12 per cent support. He first entered politics as a special adviser to the Finance Minister, Ivan Mikloš, with whom he shared responsibility for the bold reform of the Slovak taxation system in 2003-04. The reform radically simplified the Slovak taxation system through the introduction of a 'flat tax' amounting to just 19 per cent on all income. The tax reform is credited with a significant improvement in the Slovak economy, which is still considered one of the most dynamic within the eurozone (though admittedly starting from a very low level). At any rate, what Mikloš and Sulík accomplished made Slovakia very attractive to foreign investors and reinforced the ongoing process of Europeanisation. These were not policies of a provincial, let alone an anti-European government. It is safe to assume that Sulík's surprising success in the 2010 elections was related to the overall success of these policies, for which he was able to take some credit.

Through his upbringing and his political outlook, Sulík too is thoroughly Europeanised. Thanks to his commercial success, he also happens to be one of the richest individuals in Slovakia. He spent his formative years in (what was then) West Germany. His family emigrated through the former Yugoslavia in 1980, when he was only twelve. His secondary education took place first in Munich, then in Gelsenkirchen, and led finally to a leaving certificate at the Technical High School in Pforzheim (Technisches Gymnasium). He proceeded to study physics at the Ludwig Maximilian University in Munich, only to switch to economics in 1989 (Betriebswirtschaftslehre). Sulík discontinued his studies in order to return to Slovakia, which, after the collapse of communism, offered great opportunities for young, daring entrepreneurs. He founded a company (FaxCopy), made his fortune and then successfully completed his degree at the Economic University in Bratislava. ${ }^{37}$

Sulík's return to Slovakia and his transition from the private sector into politics were not without setbacks. The Slovak media developed a love-hate relationship with the former expatriate well before his controversial stance towards eurozone policies. Immediately after the 2010 elections, he accepted a prominent political role as the Speaker of the Slovak Parliament (defying expectations that he might

36 Policy making under extreme circumstances, Opening panel of the 42nd St Gallen Symposium, 3 May 2012, <http://www.youtube.com/watch?v=iu7VfSzHPA4>

37 Remarkably, Sulík's final thesis produced at the Economic University, 'Daňová reforma SR [Tax reform of the Slovak Republic]', served as a blueprint for the radical transformation of the Slovak taxation system. The thesis is available at: <http://diplomovka.sme.sk/zdroj/3431.pdf> (viewed 30 May 2012). 
become the Finance Minister). A few days after his nomination, Sulík attended an informal lunch with the Austrian, German and Swiss Ambassadors, where he learned his first lesson about managing appearances. Newspapers accused him of not doing justice to his newly acquired political role, because he failed to dress properly for such a meeting. ${ }^{38}$ In Slovakia such behaviour is considered a major faux pas. Sulík dressed like what Slovaks call dismissively a Gadžo (a provincial, uncultivated peasant); what's more, he did this in the presence of sophisticated Westerners. This trivial episode received a considerable amount of press coverage. It was a revealing manifestation of the deep-seated anxiety among the Slovak people that they would not be accepted as equals in the family of European nations: sitting at the table with sophisticated, rich and powerful nations like the Swiss, Austrians and Germans. Sulík was blamed for embarrassing the nation by looking like a barbarian. ${ }^{39}$

What is, in fact, ironic about Sulík's short political career is that rather than being a Slovak populist, he seems to have internalised distinctly 'Germanic' virtues, which manifest themselves, in particular, in his strong belief that for a polity to be successful it must be rule-based. This is at the heart of the German conception of the Rechtstaat - that is, the rule of law that ought to underpin a liberal-democratic state. ${ }^{40}$ German elites, arguably more than anyone else, have consistently seen the project of European integration as one based on a stable supranational legal order. For the European Union to survive, it must remain primarily a community of law. This argument spans half a century, from Dr Walter Hallstein, ${ }^{41}$ the first president of the European Commission, to current commentaries by the likes of Professor Paul Kirchhof, ${ }^{42}$ a former judge of the German Constitutional Court, and Jens Weidman, ${ }^{43}$ the President of the German Bundesbank.

\footnotetext{
38 See 'Sulík na večeri s vel'vyslancami: Šéf parlamentu sa správal ako sedliak! [Sulík's dinner with ambassadors: the president of the parliament behaved like a peasant]', Nový čas, 28 July 2011, <http:// www.cas.sk/clanok/175018/sulik-na-veceri-s-velvyslancami-sef-parlamentu-sa-spraval-ako-sedliak.html> and 'Oblečte si svojho Sulíka! Zvládnete to lepšie, než predseda parlamentu? [Dress up your Sulík! Will you manage it better than the president of the parliament?]', Nový čas, 30 July 2011, viewed 31 May $2012<$ http:// www.cas.sk/clanok/175292/oblecte-si-svojho-sulika-zvladnete-to-lepsie-nez-predseda-parlamentu.html> 39 Parenthetically, it is worthwhile noting that the theory of two kinds of nationalism mentioned above is particularly offensive to nations in Central and Eastern Europe for very similar reasons. To argue that a nation has a strong proclivity to subscribe to Eastern nationalism amounts to questioning its rightful place in Europe to the extent that Europe is usually equated with the West. Following this logic, to be described as 'East European' implies that one is less European.

40 See, for example, Smith, G. 1981, 'Does West German democracy have an "efficient secret"?', West European Politics, vol. 4, no. 2, pp. 166-76, at p. 171. The strict adherence to the rule of law stabilised the post-World War II political system in West Germany, creating what Jan-Werner Müller described as 'constrained democracy'. Müller, J.-W. 2011, Contesting Democracy: Political thought in twentieth-century Europe, Yale University Press, New Haven, Conn., p. 6.

41 Hallstein, W. 1969, Der unvollendete Bundesstaat, Econ, Düsseldorf \& Vienna.

42 Kirchhof, P. 2012, 'Verfassungsnot!', Frankfurter Allgemeine Zeitung, 12 July.

43 Weidmann, J. 2012, 'Nur eine Stabilitätsunion kann den Euro retten', Der Standard, 27 June.
} 
This leads to the second decisive moment in Sulík's political biography, which occurred in October 2011, when he defied both domestic and EU pressure to endorse the enlargement of the European Financial Stability Facility (EFSF). In his defence, one can plausibly argue that by rejecting the EFSF he simply remained truthful to what he promised his voters a year earlier, when, alongside his coalition partners, he vehemently opposed the bailout of Greece.

How did Sulík's actions reflect his own self-understanding and how did they impact on Slovak self-understanding? Here, again, it helps to follow Hearn's lead: 'How and why do people invest themselves in nations and nationalism? An important part of the answer lies in the ways that constructions of narrative and agency at the collective level articulate with experiences of narrative and agency at the personal level. ${ }^{\prime 4}$

Reflecting on Hearn's triangle of 'narrative, agency, and mood', it becomes clear that Sulík's controversial actions played out at two levels concurrently: at the levels of Slovak and EU politics, which impacted on both Slovak and German national debates. The narrative that emphasised rules was strongly anchored in German political culture, but might have found resonance with the Slovak electorate, particularly when Sulík contrasted Slovak compliance with the provisions of the Maastricht Treaty with Greek - and indeed, German and French - transgressions of the same provisions. His 'agency and mood' as a selfproclaimed 'oddball' defying external pressure were primarily directed towards Slovaks, who were keen to escape their past status as a 'subservient, subject people'. ${ }^{45}$

In an hour-long programmatic speech to the Slovak Parliament on 21 June 2012, in which he outlined his party's fundamental objections to the establishment of the European Stability Mechanism (which was meant to eventually replace the temporary EFSF), Sulík implored Members of Parliament and the Slovak Prime Minister to resist the pressure from Brussels:

I challenge Robert Fico, the premier of our country who pledged that he will fulfill his duties in the best interests of Slovak citizens and not in the interests of a handful of unelected officials in Brussels, to reject the Treaty about the European Stability Mechanism from his position of the Prime Minister. Mr Fico, it is your moral duty to protect Slovak national interests and not to damage them. To be a statesman does not mean that

44 Hearn, 'Narrative, agency, and mood', p. 745.

45 Hríb, 'Lampa o páde vlády a eurovale'. 
one simply obediently follows the instructions from Brussels, in order to be popular there [a byt' tam za fešáka]. To be a statesman means to act in one's country's interest. ${ }^{46}$

It is worthwhile repeating that this position is not incompatible with Sulík's support for European integration per se. Asked about the possibility of giving up national sovereignty in the German weekly Stern, Sulik accepted that it would make perfect sense for Slovakia to do so in the area of the Common Foreign and Security Policy, which is precisely the area in which the European Union has achieved very little. Yet, only those who are 'fixated on the idea of the United States of Europe and are willing to risk everything [to implement that vision]', Sulík argued, are considered 'good Europeans'. Queried about whether he had any regrets about threatening the collapse of the eurozone through his October 2011 opposition to the EFSF, Sulík retorted: 'I haven't changed my mind. The bailout of Greece was wrong. Following my personal initiative we rejected it [in 2010]. We did not succumb to blackmail. I know that I am viewed as a bad European by the politicians in Brussels. The good ones are those who obey. ${ }^{\prime 47}$

Clearly, Sulík implied that such views about 'good Europeans' are one-sided. His proposition was credible. It is worth recalling that from the outset, the process of European integration was driven by competing visions for Europe. Although the founding Treaty of Rome promised 'an ever-closer union' already in 1957, the aims of the founding fathers were more modest. Indeed, as Alan S. Milward argued in his seminal study, the pragmatic realism of the postwar leaders and their legitimate concern with national interests resulted in the 'European rescue of the nation state'.$^{48}$ Sulík is, hence, right to invoke the legacy of the French Foreign Minister, Robert Schuman, when stressing the importance of national interests in Europe. ${ }^{49}$ In Sulík's defence, it can be argued that the reckless policies pursued to maintain the integrity of the eurozone at any price are not just against German and Slovak national interests, they do not serve European interests either. ${ }^{50}$

Sulík's determined opposition to the eurozone rescue policies was based on two strands of argumentation. First, any talk about the need for more European

\footnotetext{
46 Published on YouTube by Sulík's party, Freedom and Solidarity, under the title 'Essential speech by Richard Sulik about the ESM madness', <http://www.youtube.com/watch?v=y8KSBykRJl8> and 'Grundsatzrede von Richard Sulík zum Wahnsinn namens ESM', <http://www.youtube.com/watch?v=6N va_51lQ6M\&list=UUDwcHhCZOwHb6sguW4O6XBg\&index $=7 \&$ feature=plcp $>$ It is worthwhile noting that the speech is published with both German and English subtitles, demonstrating Sulík's determination to reach beyond the Slovak electorate.

47 'Die Vereinigten Staaten von Europa sind eine fixe Idee', [An interview with Richard Sulík], Stern, 29 August 2012, <http://www.stern.de/politik/ausland/richard-sulik-slowakischer-politiker-die-vereinigtenstaaten-von-europa-sind-eine-fixe-idee-1886108.html>

48 Milward, A. 1992, The European Rescue of the Nation-State, Routledge, London.

49 'Die Vereinigten Staaten von Europa sind eine fixe Idee'.

50 I developed this point further in Auer, S. 2012, Whose Liberty is it Anyway? Europe at the crossroads, Seagull Books, Calcutta, pp. 81-2.
} 
solidarity was misguided considering the massive discrepancy in per capita income between Slovakia and Greece, accompanied by significantly lower levels of spending on basic infrastructure and welfare support in the former in contrast with the latter. Slovakia was asked to support spendthrift countries that were significantly richer but incurred unsustainable levels of debt. In effect, or so Sulík argued, the Slovak electorate was being punished for supporting governments that had behaved in a fiscally prudent manner. Second, Slovakia was initially proud to join an elite club of eurozone countries in 2009, assuming that what kept the club together was a set of strict rules. After all, Slovakia's entry was preceded by great efforts made in order to comply with the stringent demands of the Maastricht Treaty: an overall level of debt lower than 60 per cent of gross domestic product (GDP) and a deficit no higher than 3 per cent. Slovak liberals, including Sulík, ${ }^{51}$ welcomed the external pressure that would force Slovak governments to behave in a fiscally prudent manner.

The Maastricht criteria, however, were not applied in the same way to all the countries of the eurozone. Before its admission to the single currency in January 2009, Slovakia was scrutinised far more thoroughly than any other existing member state. While the admission of Greece was made possible regardless of its deficiencies with respect to fiscal discipline - the 'cradle of democracy' was seen as a symbolically important partner in the enterprise that aimed to foster a sense of pan-European identity - the admission procedures applied to the countries in Central and Eastern Europe were significantly more rigorous.

Sulík favoured a rule-based approach. As he noted in his speech to the Cato Institute in February 2012: 'In the first 10 years of single currency the Maastricht criteria were broken 97 times, but no country was punished. In 2004 Germany and France publicly declared that they will not follow the Maastricht criteria.'52

What particularly angered Sulík and many of his supporters was the fact that Greece had falsified its statistics for years, well before the escalation of the eurozone crisis. In fact, as noted above, the electoral success of the centreright governing coalition, of which Sulík's party became a member in 2010, was partly based on their rejection of the first bailout of Greece. As the eurozone crisis deteriorated further in 2011-12, EU leaders and national politicians felt compelled to pursue policies that further violated the provisions anchored in the Maastricht Treaty in order to preserve the currency union. Furthermore, the independence of the European Central Bank was compromised by its purchases of government bonds on secondary markets; the no-bailout clause in

\footnotetext{
51 'This is exactly the kind of stability community [Stabilitätsgemeinschaft] that we want to belong to', Sulík recalled years later. See Fischer, P. 2012, 'Der Euro führt so in die Knechtschaft', Neue Zürcher Zeitung, 25 June, $<$ http://www.nzz.ch/aktuell/wirtschaftnachrichten/der-euro-fuehrt-so-in-die-knechtschaft-1.17277615> 52 Sulík, R. 2012, European integration: what's gone wrong?, Address to policy forum, CATO Institute, Washington, DC, 21 February, <http://www.cato.org/event.php?eventid=8836>
} 
the Maastricht Treaty was violated through the refinancing of Greek, Irish and Portuguese sovereign debt. This was anathema to a number of influential critics in Germany-Olaf Henkel, Axel Weber and Thilo Sarrazin ${ }^{53}$ — as well as Sulík. As he wrote (together with Marian L. Tupy) in February 2012:

After the fall of the Berlin Wall, Slovakia underwent painful but necessary economic reforms, with the burden of the transition to capitalism squarely on the shoulders of the Slovak people. Meanwhile, Greeks were enjoying artificial prosperity stimulated by government borrowing and spending. The average income in Slovakia was $\$ 17,889$ in 2011; in Greece, it was $\$ 27,875$. The average Slovak pension was $\$ 491$ in 2010; in Greece, it was $\$ 1,775$. Slovakia's national debt is $45 \%$ of GDP; Greek debt is approaching $160 \%$.

Yet Slovakia is now being asked to borrow in order to lend to Greece, thereby sacrificing its relatively high credit rating and low interest rates. Is this solidarity? This kind of 'solidarity' with Greece also flies in the face of the rule of law. Article 125 of the Lisbon Treaty, for example, states that each EU member state is responsible for its own debts, and Article 123 prohibits the European Central Bank from lending to the EU member states. Both stipulations have been breached. ${ }^{54}$

As noted above, Sulík's criticism of the eurozone rescue policies appears to have received stronger support from abroad than in his native Slovakia. His actions attracted attention from a wide variety of well-respected foreign media outlets, such as the Wall Street Journal (see above), and German newspapers such as the Frankfurter Allgemeine Zeitung, Spiegel and Stern magazines and the weekly Die Zeit. The Swiss monthly the Schweizer Monat featured Sulík on its cover, presenting a lengthy interview with 'the preacher' (Prediger) of fiscal responsibility.

More recently, Sulík directly entered the public discourse in Germany by responding to an article in Die Zeit, written by a German MEP for the Green Party, Franziska Brantner. Expressing her frustration with the German Government, Brantner argued that German politicians should be more honest with their electorates and admit that the pooling of debt across Europe is both necessary and just, even though it will expose Germany to further liabilities. It is necessary because the eurozone cannot survive without it, and it is just because of Germany's historical responsibility towards its European partners. ${ }^{55}$

53 Henkel, H.-O. 2010, Rettet unser Geld!, Heine, Munich; Sarrazin, T. 2012, Europa braucht den Euro nicht: Wie uns politisches Wunschdenken in die Krise geführt hat, Deutsche Verlags-Anstalt, Munich.

54 Sulík, R. and Tupy, M. L. 2012, 'The limits of European solidarity', Wall Street Journal, 15 February.

55 Brantner, F. 2012, 'Weil wir nicht ehrlich sind', Die Zeit, 2 August, <http://www.zeit.de/2012/32/EuroKrise-Schulden-Brantner/komplettansicht> 
In response, Sulík recalled his school years in West Germany, in which he learned a great deal about Germany's guilt and its massive reparation payments. 'It was right that Germany paid so much', Sulík argued, 'after all it had caused immense damage. But for how much longer is it expected to pay now in the Eurozone crisis?'56 Sulík's article elicited hundreds of reader comments, mostly positive, with many readers exasperated by the fact that Germans needed to be told by an outsider how to best look after their own and Europe's interests.

Sulík also found a sympathetic response in Poland. Gazeta Prawna, for example, ridiculed EU Commission President José Manuel Barroso's attack on Sulík. Barroso argued: 'sovereignty is fine, but you cannot allow a small stakeholder in the community [Slovakia] to slow down all the others.' 'It goes without saying', opined the Polish commentator, that 'the UK, France and Germany can veto any major development without inviting any criticisms'.$^{57}$

In contrast, Ivan Mikloš, the then deputy prime minister and minister of finance from the ruling Slovak Democratic and Christian Union, accused his former coalition partner of employing Goebbels' methods:

In a desperate attempt to arrest the decline in their popular support, Sulík and his party, Freedom and Solidarity, resorted to populism and destroyed their own government. They displayed a complete disregard not merely for the solutions advanced for the Eurozone crisis and for Slovak foreign policy, but for politics as such... The spread of phobia against the establishment of the protective bailout fund failed, so instead of advancing a real political program they resorted to relentless attacks, baseless accusations and manipulations. ${ }^{58}$

As noted above, one of the remarkable paradoxes of Sulík's EU politics is that it might have been more successful in Germany than in his native Slovakia. His principled position resonates with German political culture. In June 2012, Sulík was even awarded the Hayek Award by the Friedrich A. von Hayek Society. As the Neue Zürcher Zeitung reported, Sulík addressed the Friedrich A. von Hayek Society gathering, reminiscing about his initial enthusiasm for the single currency as the bedrock of fiscal prudence and stability. As it happened though, Sulík warned his audience gathered in Bayreuth, 'the Euro now leads to serfdom'. ${ }^{59}$

\footnotetext{
56 Sulík, R. 2012, 'Deutschland ruiniert sich', Die Zeit, 9 August, <http://www.zeit.de/2012/33/EuroRettung-Zahlung-Deutschland>

57 Parafianowicz, Z. 2011, ‘Europejczycy równi I równiejsi', Gazeta Prawna, 14 October.

58 Mikloš, I. 2012, 'Sulíkova politika je mimo reality', Hospodárske noviny, 23 January, p. 7.

59 Fischer, P. 2012, 'Der Euro führt so in die Knechtschaft', Neue Zürcher Zeitung, 25 June, <http://www. nzz.ch/aktuell/wirtschaftnachrichten/der-euro-fuehrt-so-in-die-knechtschaft-1.17277615>
} 
Well before Sulík received the award, a Slovak commentator speculated that his uncompromising stance was reinforced through the prominence he gained in Germany, which must have been particularly flattering for someone who could not have reached such elevated status while living there. Samuel Abraham, a leading Slovak public intellectual, wrote a personal attack on Sulík for the large Slovak daily Sme (7 October 2011), alleging that his misguided positions were driven by the vanity of an expatriate who wanted to prove himself in Germany:

Wherever you end up as an immigrant, you become just an observer in that new society...And now imagine Richard Sulík, who lived and studied in the émigré anonymity of the Federal Republic of Germany. He can suddenly see how his speeches about the Euro bailout fund make it to the front page of [German] newspapers that he used to read with reverence. He takes part in a TV talk-show in Berlin to explain the downsides of the Euro rescue efforts to those very Germans who had ignored him until now. This amounts to a perfect satisfaction for a former emigrant.

He earned himself Warhol's five minutes of fame across all of European inducement stronger than his political career in the province. ${ }^{60}$

Yet even in Slovakia, where Sulík was often dismissed as a one-issue-party leader for one electoral term, he proved his critics and political opponents wrong. He was re-elected to the Parliament in March 2012, defying an exceedingly hostile media environment and relying largely on simple use of new social media and the Internet. This is not to underplay the significant decline in support for his party, which secured only 6 per cent compared with 12 per cent at the previous election.

While the election campaign of Sulík's SAS party focused on the unfair deal that the Slovak Government accepted through its support of the euro-rescue policies, ${ }^{61}$ the March 2012 elections were overshadowed by a massive corruption scandal that implicated leading political figures in the centre-right parties. Even Sulík was involved, if only in a minor way, in the so-called Sasanka affair. ${ }^{62}$ Sulík

\footnotetext{
60 Abrahám, S. 2012, ‘Europopulizmus: pät' minút slávy Richarda Sulíka [Europopulism: five minutes of Richard Sulík's fame]', Resetované Slovensko: čistá teória vs. politická prax [Slovakia Reset: Pure theory versus political practice], Kalligram, Bratislava, pp. 44-8.

61 The short and snappy party video released on the eve of the March 2012 elections emphasises Sulík's personal integrity and his determination to defend the interests of Slovak citizens against misguided EU policies. It contains also the highlights of Sulík's appearances on German TV and the British MEP Nigel Farage's endorsement of Sulík. See the YouTube video 'Vol'by 2012: Kto koná v záujme občanov? [Elections 2012: who acts in the interests of citizens?]', viewed 30 May 2012, <http://www.youtube.com/watch?v=eT Uy4DLskd4\&feature=youtu.be>

62 'Another anonymous document named "Sasanka" emerges', The Slovak Spectator, 30 January 2012, viewed 31 May 2012, <http://spectator.sme.sk/articles/view/45221/2/another_anonymous_document_ named_sasanka_emerges.html>
} 
could not deny that he met on numerous occasions with the highly dubious entrepreneur Marián Kočner, who exploited his connections with a wide crosssection of Slovak politicians across the ideological divide. The allegations undoubtedly dented SAS's and Sulík's credibility as fighters against corruption, and, as Sulík himself admitted, they might have cost the party valuable electoral support. ${ }^{63}$ Sulík accepted that the meetings were imprudent, but blamed himself for being politically naive, rather than corrupt. What cannot be doubted is the fact that the scandal diverted people's focus from the eurozone crisis. ${ }^{64}$

\section{Concluding Remarks}

The eurozone crisis has had a decisive impact on the Slovak political landscape by creating new political cleavages. The liberal-nationalist forces, which were unable to maintain unity in November 2011 with respect to the enlargement of the euro-rescue fund, were punished by the Slovak electorate in March 2012. The main beneficiary in the 2012 elections was Robert Fico, the leader of the centre-left party Smer, which gained an absolute majority and was able to govern without the support of any minor parties. Fico's European credentials were somewhat mixed in 2006-10 owing to his alliance with the extreme right Slovak Nationalist Party; Smer was even temporarily expelled from the alliance of European Social Democratic Parties. Yet, in 2012, Fico could credibly present himself as a 'good European'. He showed no doubts about the need for Slovakia to support the euro-rescue policies. It is not without irony that Fico, who did not hesitate to enter into a governing coalition with the party of extreme nationalists in 2006, became the main beneficiary of the European Union's pressure on the Slovak centre-right government. In fact it was Fico, rather than Sulík, who repeatedly demonstrated populist tendencies. Another article would be needed to describe and analyse Fico's enduring allure to the Slovak people and what it can tell us about the competing conceptions of nationalism in Slovakia. Measured against Fico's popularity, Sulík is - and is likely to remain - only a marginal political actor.

Yet Sulík's non-conformist thinking resonates with a small but remarkably stable segment of the Slovak electorate. Moreover, it is yet to be fully vindicated. Further escalation of the eurozone crisis is bound to strengthen his clout both in Slovakia and in Europe. Owing to the crisis, Slovaks as a nation are being forced to rethink their love affair with Europe. Like other peoples across the European Union, they are learning the hard way that EU membership is not always a win-win proposition. What Sulík's short political career also shows is

63 'Instead of achieving about 6 per cent', Sulík stated, 'we could have had about 8 per cent'. An interview with the author conducted in Bratislava, 26 June 2012.

64 Zsilleová, M. 2012, 'Európa strany v kampani nebaví', Sme, 15 February. 
that politics within EU member states can no longer be constrained to national matters. In fact, through his outlook, personal biography and political actions, Sulík has sought to influence both Slovak and European politics. He also became increasingly aware of himself as a European political actor. An entrepreneur who became a politician out of a strongly held belief that this was the only way to make his society more free, he found a new calling in response to the (mis-)management of the eurozone crisis. He exemplifies what Hearn finds so rewarding about the study of nationalism, biography and power:

[T] he search for power is not simply a matter of domination, but also an existential aspect of being human. As healthy individuals, we need to have some power over our lives, and this search gets inscribed in our identities, and laid down in our biographies. The various ways people connect and disconnect their personal identities...reveal struggles for and against power. ${ }^{65}$

As this article was being finalised, Sulík saw himself as being on a mission to save Europe from itself-or, to be more specific, what he considered to be its incompetent and reckless leadership in Brussels, Berlin and Paris. Somewhat isolated, but no longer alone, Sulík sketched the beginnings of a tentative alliance that spanned political 'oddballs' in Germany, the United Kingdom and Slovakia. As he put it in an interview with the Schweizer Monat:

I see myself as a part of a splinter group, a European avant-garde, that includes [the MPs] Frank Schäffler and Peter Gauweiler in Germany and [the MEP] Nigel Farage in England. We travel through Europe in order to spread enlightenment. We are the thorns in the eyes of the EU dreamers. We denounce the crooked deals of Merkels, Hollandes and Junckers, who meet every couple of weeks at various crisis summits and continue turning the European Union into a monster in the name of solidarity and justice. We feel at times like Jehovah's Witnesses, but it is also fun. ${ }^{66}$

Sulík might be posturing here and overestimating his influence; yet, this is clearly not a statement of a parochial nationalist or an opportunistic populist (even if Sulík is doing himself a disservice through his association with Nigel Farage, whose relentless criticism of the European Union is far more radical). Sulík's story is interesting precisely because it reflects and shapes a small, but increasingly influential strand in the Slovak political spectrum that is in its outlook and commitments both liberal and national, European and Slovak. The suspicion of centralised power and the supranational bureaucracy of EU institutions goes hand-in-hand with the commitment to a Europe of open markets

65 Hearn, this volume.

66 Scheu, R. 2012, 'Der Prediger', Schweizer Monat, no. 998 (July-August), <http://www.misesinfo. $\operatorname{org} / \mathrm{p}=2650>$ 
and its four freedoms that have defined the project of European unity from the outset: the freedom of movement of people, capital, goods and services. Seen in this light, a liberal defence of Slovak national interests is not incompatible with the pursuit of European interests.

Sulík is not a populist. In fact, committed as he is to fiscal prudence, Sulík has consistently opposed populist policies pursued by politicians willing to spend money on reckless electoral promises. What Sulík presented to the electorate was the necessity of cutting spending; he also opposed the tax on high earners - such political positions are unlikely to attract much popular support. Even Sulík's personal background does not lend itself to populism. A populist is someone deeply steeped in the political culture of his country, for whom telling the people what they want to hear is second nature. As a former expatriate, Sulík took some time to readjust to his homeland; as an outsider to politics, he took time to adjust to political games. He remains a committed liberal nationalist who, by defending Slovak national interests, defends European interests too (or what he perceives them to be). In fact, it may well be argued that European politics would benefit from having more politicians like Sulík.

To democratise itself, the European Union needs to open itself to radically different views about its future. European elites ignore the views of their electorates at their peril. If the mainstream political parties in Europe and their leaders fail to address the legitimate concerns of their nations, more extremist leaders will do so. As a result, the future students of European politics might end up being confronted with the revival of ethnocentric nationalism in an increasingly divided Europe, rather than various strands of liberal nationalism, which seek to combine commitment to one's own nation with universal liberal values. 